\title{
Syphilis presenting as acute syphilitic posterior placoid chorioretinitis
}

\author{
Deepesh Mehta, Kenneth Chan
}

Ophthalmology, Capital and Coast District Health Board, Wellington, New Zealand

Correspondence to Dr Deepesh Mehta; mehde493@gmail.com

Accepted 15 June 2021

\section{DESCRIPTION}

A 59-year-old man who has sex with men presented to the emergency department with a 1-week history of bilateral central vision loss. Visual acuity (VA) was 6/60 and 6/18 in the left and right eye, respectively. Slit-lamp examination revealed mild, bilateral anterior and intermediate uveitis, optic nerve head swelling, placoid lesions at the macula and chorioretinitis encompassing the optic nerve and macula in a circinate distribution (figure 1). Haematological investigation revealed a reactive enzyme immune assay and a rapid plasma reagin titre of 1:160, suggestive of acute syphilitic posterior placoid chorioretinitis (ASPPC).

Syphilis is a systemic infection secondary to the spirochete Treponema pallidum, of which the incidence is increasing in developed nations, especially in specific groups such as men who have sex with men and intravenous drug users. ${ }^{12}$ Moreover, syphilis can commonly present as a coinfection with HIV. $^{12}$ The manifestations of syphilis are vast and can often masquerade as different systemic and ophthalmological presentations leading to delay of diagnosis and management and potential irreversible visual loss. ${ }^{12}$

ASPPC is a rare manifestation of ocular syphilis, with placoid lesions likely developing secondary to chorioretinal inflammation with outer retinal immune complex deposition, although the exact pathophysiology is not known. ${ }^{13}$ Optical coherence tomography in patients affected by ASPPC is useful in aiding diagnosis and reveals disruption of the outer ellipsoid zone and nodular lesions from the retinal pigmented epithelium (figure 2 ). ${ }^{23}$

Treatment of this entity primarily involves the use of antibiotics. In some instances, anti-inflammatory agents such as tumour necrosis factor alpha inhibitors or corticosteroids may be considered to reduce

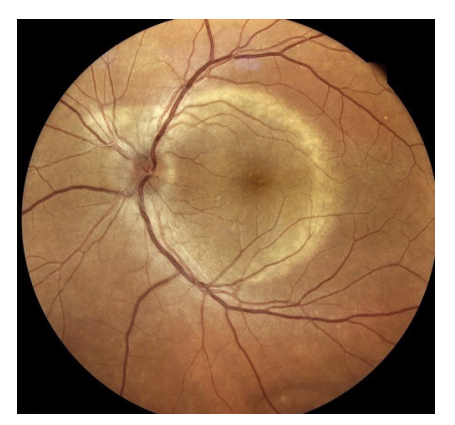

Figure 1 Fundus photograph of the left eye showing optic nerve head swelling, yellow placoid lesions at the macula and chorioretinitis encompassing the optic nerve and macula in a circinate distribution.

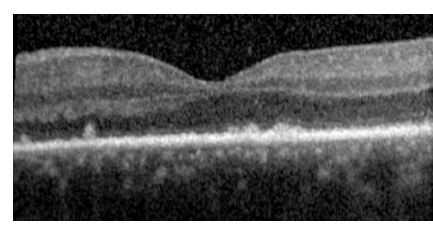

Figure 2 OCT showing diffuse loss of the outer ellipsoid zone and nodular irregularity of the retinal pigmented epithelium and outer retina. OCT, optical coherence tomography.

inflammation and to prevent Jarisch-Herxheimer reaction. ${ }^{134}$ The patient was initially treated with intravenous benzylpenicillin for two weeks and a tapering course of prednisone initiated 36 hours after commencing antibiotics. At 11-week final follow-up, the VA was 6/9 bilaterally and there was regression of the outer retina placoid lesions.

\section{Learning points}

The incidence of syphilis is increasing especially in groups such as men who have sex with men and intravenous drug users.

- Syphilis should be investigated in patients presenting with acute chorioretinitis.

- Treatment of acute syphilitic posterior placoid chorioretinitis primarily involves the use of antibiotics such as intravenous benzylpenicillin and anti-inflammatory agents may be considered in some cases.

Contributors DM is the main author of this manuscript. All listed authors were involved in the care of the patient, gave suggestions and reviewed the manuscript prior to submission.

Funding The authors have not declared a specific grant for this research from any funding agency in the public, commercial or not-for-profit sectors.

Competing interests None declared.

Patient consent for publication Obtained.

Provenance and peer review Not commissioned; externally peer reviewed.

\section{REFERENCES}

1 Pirani V, Pelliccioni P, De Turris $S$, et al. The eye as a window to systemic infectious diseases: old enemies, new imaging. J Clin Med 2019;8:1392.

2 Dutta Majumder P, Chen EJ, Shah J, et al. Ocular syphilis: an update. Ocul Immunol Inflamm 2019;27:117-25.

3 Brito P, Penas S, Carneiro A, et al. Spectral-Domain optical coherence tomography features of acute syphilitic posterior placoid chorioretinitis: the role of autoimmune response in pathogenesis. Case Rep Ophthalmol 2011;2:39-44. 


\section{Images in...}

Copyright 2021 BMJ Publishing Group. All rights reserved. For permission to reuse any of this content visit https://www.bmj.com/company/products-services/rights-and-licensing/permissions/

BMJ Case Report Fellows may re-use this article for personal use and teaching without any further permission.

Become a Fellow of BMJ Case Reports today and you can:

- Submit as many cases as you like

- Enjoy fast sympathetic peer review and rapid publication of accepted articles

- Access all the published articles

- Re-use any of the published material for personal use and teaching without further permission

Customer Service

If you have any further queries about your subscription, please contact our customer services team on +44 (0) 2071111105 or via email at support@bmj.com. Visit casereports.bmj.com for more articles like this and to become a Fellow 